SCJR 15, no. 1 (2020): 1-22

\title{
Following the Breadcrumbs: Jesus as Superfluous to Salvation? A Catholic Search ${ }^{1}$
}

\author{
PETER ADMIRAND \\ peter.admirand@dcu.ie \\ Dublin City University, Dublin, D09 N920, Ireland
}

\section{Interfaith Theological Hunger}

In Jewish-Christian Dialogue: Drawing Honey from the Rock, their 2008 book which candidly and, sometimes bluntly, assessed the current state of Jewish-Christian dialogue, Jewish scholars Alan Berger and David Patterson, ask, "with fear and trembling," whether Jesus, "for the Jews, is superfluous to salvation"? ${ }^{2}$ They are challenging the Christian claim that Jesus is the sole, unique, universal saviorand the standard Christian belief that Jesus' death on the cross was needed to redeem all of humanity from original sin (an issue I will address further below). My contention here is not on the full merit of Berger and Patterson's assessments about Christianity in the book, which includes solid Christian responses and counterclaims from David P. Gushee, John T. Pawlikowski, and John K. Roth. I highlight Berger and Patterson's question because it cuts to the heart, not only of JewishChristian relations, but of Christian identity. ${ }^{3}$ To build on their question, I am asking whether the Christian belief that Jesus is the unique, sole, universal savior of the world (and so all other ways are flawed and insufficient) has not only damaged

\footnotetext{
${ }^{1}$ An initial version of this essay was presented at "Fulfilling the Promise of a New Relationship: An Academic Roundtable on Christian-Jewish Relations," sponsored by the Institute for Catholic-Jewish Relations, Saint Joseph's University, Philadelphia (January 2019), with a response from Philip Cunningham. I thank Phil for his comments, and along with Adam Gregerman, their gracious hosting of us. A subsequent version was then presented at a panel on Muslim-Christian Dialogue (organized by Mario Aguilar) at the $2^{\text {nd }}$ European Academy of Religion Conference in Bologna in March, 2019. This challenged me to ask how a paper originally presented to a select group of Jewish-Christian dialogue experts would or should be adapted for a panel on Muslim-Christian dialogue with listeners from a range of backgrounds and beliefs. One area that arose is how the Catholic prioritizing of the relationship with Jews and Judaism appears in a more religiously mixed environment.

${ }^{2}$ Alan L Berger and David Patterson, with David P. Gushee, John T. Pawlikowski, and

John K. Roth, Jewish-Christian Dialogue: Drawing Honey from the Rock (St. Paul: Paragon House, 2008), 124 and 180-181.

${ }^{3}$ For a scathing critique of Berger and Patterson's interpretations of Christianity, which she calls "a caricature" and in need of much refinement, see Mary C. Boys' review of Jewish-Christian Dialogue: Drawing Honey from the Rock in Studies in Christian-Jewish Relations Volume 5 (2010): Boys R1-2, https://ejournals.bc.edu/index.php/scjr/article/view/1569/1422.
} 
relations, views, and interpretations of Judaism and the Jewish people, but has damaged and undermined Jesus' commandment: "Just as I have loved you, you also should love one another" (John 13:34). ${ }^{4}$ Has such theological certitude and inflexibility created a Christianity very adept at judging and critiquing others while overly confident of its need to protect, defend, and justify its own positions as the only correct ones?

In light of more recent Church pronouncements, like the 2015 Vatican document "The Gifts and the Calling of God Are Irrevocable,", I, also in fear and trembling, want to follow a number of (theological) "breadcrumbs" to see where they lead me in light of the Church's orthodox and standing claim of Jesus' unique and universal salvific role, namely: the proclaimed Jewishness of Jesus; the Church's post-Shoah embrace of Christianity's Jewish foundations; the Church's distancing from supersessionism ${ }^{6}$ (and its call to reject what Didier Pollefeyt labels "Christological triumphalism"7); the proclamation of the ongoing validity of the Jewish Covenant (mentioned by John Paul II in Mainz in 1980); and the Church's rejection of systemic, institutional attempts to convert the Jewish people. ${ }^{8}$ In this

\footnotetext{
${ }^{4}$ All biblical translations are from the NRSV, Catholic Edition.

${ }^{5}$ Commission for Religious Relations with the Jews, “"The Gifts and the Calling of God Are Irrevocable' (Rom 11:29): A Reflection on the Theological Questions Pertaining to Catholic-Jewish Relations on the Occasion of the 50th Anniversary of 'Nostra Aetate' (No. 4)" (December 10, 2015), http://www.vatican.va/roman curia/pontifical councils/chrstuni/relations-jews-docs/rc pc chrstuni doc 20151210 ebraismo-nostra-aetate en.html. For analysis, see Christian M. Rutishauser, "Christian Mission to the Jews Revisited: Exploring the Logic of the Vatican Document 'The Gifts and Calling of God are Irrevocable'," Studies in Christian-Jewish Relations 14 (2019): 1-16, https://ejournals.bc.edu/index.php/scjr/article/view/11587; and Marianne Moyaert, "'The Gifts and the Calling of God Are Irrevocable' (Rom 11:29): A Theological Reflection," Irish Theological Quarterly 83, no.1 (2018): 24-43.

${ }^{6}$ Understandably, much of the Jewish and Catholic world were confused (or distressed) by Emeritus Pope Benedict's remarks that supersessionism cannot be seen as an ancient Church belief or tendency, citing, as "evidence" its absence from German theological lexicons. See Benedict XVI, "Grace and Vocation without Remorse: Comments on the Treatise De Iudaeis," Communio 45, no.1 (Spring 2018): 163-184, https://www.communio-icr.com/articles/view/grace-and-vocation-without-remorse. For helpful commentary and views, see the following link from the Council of Centers on Jewish-Christian Relations: https://www.ccjr.us/dialogika-resources/themes-in-today-s-dialogue/emeritus-pope. See also Philip A. Cunningham and Adam Gregerman, “"Genuine Brotherhood"” without Remorse: A Commentary on Joseph Ratzinger's 'Comments on 'De Iudaeis," Studies in Christian-Jewish Relations 14 (2019): 1-29, https://ejournals.bc.edu/index.php/scjr/article/view/11925/9823. Cunningham and Gregerman contend that the treatise is "noteworthy in the study of developments in Jewish-Christian relations" (28). Their critically fair analysis helped me be more generous towards Benedict's likely aims and meaning, though his theological oeuvre mostly leaves me pondering and frustrated.

${ }^{7}$ Didier Pollefeyt, "Christology After Auschwitz: A Catholic Perspective," in Jesus Then \& Now: Images of Jesus in History and Christology, ed. Marvin Meyer and Charles Hughes (Harrisburg: Trinity, 2001), 229-48.

${ }^{8}$ Note I am not going to rehash this already well-trod terrain, which I have done, for example, in my "Landmines and Vegetables: The Hope and Perils of Recent Jewish Critiques of Christianity," in Pathways for Interreligious Dialogue, ed. Vladimir Latinovic, Gerard Mannion, and Peter Phan (New York: Palgrave, 2016), 81-96; and in Humbling Faith: Brokenness, Doubt, Dialogue: What Unites Atheists, Theists, and Nontheists (Eugene, OR: Cascade Books, 2019), chapters 3 and 4. See also: Didier Pollefeyt, Ethics and Theology after the Holocaust (Leuven: Peeters Press, 2018); Philip A. Cunningham,
} 
light, Vatican silence towards Peter Phan's work on an "interfaith Christology" in The Joy of Religious Pluralism ${ }^{9}$ is also noteworthy. Such silence may reveal how Vatican assessment of interfaith theological exploration is developing under Pope Francis.

While bread images are rich biblically, sacramentally, and theologically, ${ }^{10}$ consider them here also like those in the fairy tale of Hansel and Gretel; or, shifting the symbol, as the red thread in the myth of Ariadne and Theseus. Such markers are meant to lead one home or serve as a means to escape the maze. In JewishChristian relations, we have encountered (and created) many mazes and we all desperately want to get home, most importantly, together, in a new relationship. ${ }^{11}$ Can I answer "yes" to Berger and Patterson's question: Is Jesus, for Jews, superfluous to salvation?, while, at Jesus' vulnerable question to the disciples, "Do you also wish to go away?," echo Peter's reply, "Lord, to whom can we go? You have the words of eternal life" (John 6:67-68)? Fused from my personal longing for Jesus both as God Incarnate and as a Jewish Galilean, ${ }^{12}$ my hope in a God of Love and Justice ${ }^{13}$ despite the problem of evil, ${ }^{14}$ and my ongoing belief that the two faiths somehow, in some way, are miraculously one even as two, ${ }^{15} \mathrm{I}$ will follow the breadcrumbs to see how and whether I can and should answer Berger and Patterson's

Seeking Shalom: The Journey to Right Relationship Between Catholics and Jews (Grand Rapids: Eerdmans, 2015); Gilbert S. Rosenthal, ed., A Jubilee for All Time: The Copernican Revolution in JewishChristian Relations (Eugene, OR: Wipf \& Stock, 2014); Alan L. Berger, ed., Post-Holocaust JewishChristian Dialogue: After the Flood, before the Rainbow (Lanham, MD: Lexington, 2014); Edward Kessler, An Introduction to Jewish-Christian Relations (Cambridge: Cambridge University Press, 2010); and Mary C. Boys, Seeing Judaism Anew: Christianity's Sacred Obligation (Lanham, MD: Rowman and Littlefield, 2005).

${ }^{9}$ Peter C. Phan, The Joy of Religious Pluralism: A Personal Journey (Maryknoll, NY: Orbis, 2017).

${ }^{10}$ See, for example, Ched Myers, Binding the Strong Man: A Political Reading of Mark's Story of Jesus, Anniversary Edition (Maryknoll, NY: Orbis, 2008).

${ }^{11}$ See, for example, the essays in Robert W. Jenson and Eugene B. Korn, eds., Covenant and Hope: Christian and Jewish Reflections (Grand Rapids, MI: Eerdmans, 2012).

${ }^{12}$ See Sean Freyne, A Jewish Galilean: A New Reading of the Jewish Story (London: Continuum, 2004).

13 The waters of liberation, postcolonial, and feminist theologies supply the majority of the theological current, purification, and nutrition here. See, for example my "Humbling the Discourse: Why Interfaith Dialogue, Religious Pluralism, Liberation Theology, and Secular Humanism Are Needed for a Robust Public Square," Religions 10, article no. 450 (2019): 1-32.

${ }^{14}$ For my investigation of theodicy, see my Amidst Mass Atrocity and the Rubble of Theology: Searching for a Viable Theodicy (Eugene, OR: Cascade, 2012).

${ }^{15}$ Discussions of the single or dual covenant remain ongoing. See, for example, Philip A. Cunningham, Joseph Sievers, Mary C. Boys, Hans Hermann Henrix, and Jesper Svartvik, eds., Christ Jesus and the Jewish People Today: New Explorations of Theological Interrelationships (Grand Rapids, MI: Eerdmans, 2011); Erich Zenger, "The Covenant that Was Never Revoked," in The Catholic Church and the Jewish People: Recent Reflections from Rome, ed. Philip A. Cunningham, Norbert J. Hofman, and Joeseph Sievers (New York: Fordham University Press, 2007), chapter 8; and John Pawlikowski, "The Search for a New Paradigm for the Christian-Jewish Relationship: A Response to Michael Signer," in Reinterpreting Revelation and Tradition: Jews and Christians in Conversation, ed. John T. Pawlikowski and Hayim Goren Perelmuter (Franklin, WI: Sheed \& Ward, 2000), 25-48. As I recognize a plurality of covenants within Judaism (the Noahide, the Abrahamic, the Mosaic, etc.), I find it neither essential nor necessary that Christians and Jews profess the same, single covenant, if that means all aspects, expectations, and thick theological language must be identical. Clearly, that is not possible in light of Jesus' professed identity for Christians. At the same time, fear of supersessionism or severing the links 
question. Such an answer, which can only be sketched here, would have profound, perhaps spiritually cataclysmic effects, not only on Christology, or related fields of Ecclesiology, Mission, Scripture, and Trinity, but also signal whether and how such breadcrumbs lead beyond the Jewish-Christian context, towards Islam and nonAbrahamic faiths.

\section{Initial Dots (Autobiographical Sketches)}

This section is unequivocally narrative-based and vulnerable. There may be some readers and scholars allergic to such methods, who mistake lyrical language for a dearth of analytical rigor, as if never the twain shall meet. Often the most convincing (or at least engrossing) analysis is the one suffused in the personal and confessional. Any turn to narrative in an academic article, however, should inflect words and phrases rooted and in dialogue with traditional scholarship, sometimes as explicit references and textual readings, sometimes as echoes, questions, and answers. The method has its risks and drawbacks and demands more of readers to connect, tease-out, and reflect.

I cannot follow any breadcrumbs or thread without identifying how I found myself in such interfaith mazes or in connecting more foundational dots or nutritive morsels. It is too personal to hide behind academic jargon and some third-person omniscient vantage point. Born in the mid-1970s in a Long Island town with wellestablished Jewish congregations, I knew little of pre-Vatican II views on the "perfidious Jews." 16 Instead, I knew Uri, from Israel, then ten-years old like me who also liked basketball and Star Wars. While I attended Catholic primary school, there were Jewish kids on my soccer teams, though I only knew them as Jason the striker with a strong left foot or Elijah (EJ) my fellow, solid defender whom I could always rely on to save goals. Bracketing my parents' house on both sides were the Silbers and the Broidos. ${ }^{17}$ The Silbers have since moved away but I still remember my deep sadness as a teenager when I was told David, the eldest son, then in his early 20 s, was battling cancer. His was the first young face I saw preternaturally bald from chemo. Fortunately, he survived. Before moving, his mother, Debbie, knowing of my interest in literature, gave me all her vintage novels of Dickens and Twain. Her kindness, and those books, have remained with me. On the other side were the Broidos. In speaking about this article to my mother, she mentioned that while she was pregnant with me, the Broidos' six-year old daughter, Nina, pointed

and connections between biblical Judaism and Christianity understandably seeks to bring the covenants as close as possible, if not to overlap at as many points as possible. While there should be a moral thrust that unites all these covenants, it seems reasonable that a God of all peoples and cultures would be comfortable with nuance, some difference, and even contradiction (again, rooted for Christians in Jesus' identity and the concept of the Trinity). See, for example, Michael Kogan, Opening the Covenant: A Jewish Theology of Christianity (Oxford: Oxford University Press, 2008).

${ }^{16}$ For analysis and commentary on the changes to this phrase in Catholic liturgy, see, for example the comments of Judith Banki and John Pawlikowski, in "Praying for the Jews: Two Views on the New Good Friday Prayer," Commonweal (10 March 2008), https://www.commonwealmagazine.org/praying-jews.

${ }^{17}$ The names of my parents' neighbors in this section have been changed to protect privacy. 
to my mom's belly and said to her, "If it's a boy you'll have a bar mitzvah but if it's a girl, you'll have a bat mitzvah." At the time, my mom was one of the few Christians on the block so she tried to explain this. The girl was incredulous: "Are you a Gentile?" My mom then told the story to Nina's mother and they both had a good laugh. The Broidos moved when I was young so I knew the Schneidermans instead. Becky, a professional violinist, was hired by the local Catholic Church to play during the Easter Triduum masses. As a child, I never considered how she felt as the only Jew in a church full of Christians shouting (supposedly as Jews), "Crucify him! Crucify him!" I think about that a lot now, though.

We were a very traditional, but still post-Vatican II, devout American Catholic family. My mother had been in the convent as a novice, with an eldest brother a priest and her elder sister a nun. My accountant father never misses Sunday mass. Saying the rosary in the living room or on car-trips still echoes in my memory. But there never was a sense of Catholic triumphalism or an institutional Church without flaws. My mother often quotes her Tipperary-born father, speaking about nonCatholics, "Ahh, all that matters is whether they be good people."

While I grew up in the context of the papacy of John Paul II, papal encyclicals and the documents of the Vatican's Congregation for the Doctrine of the Faith (CDF) never really concerned me until college. Church scandals, though, seemed to follow me like the plague. While in the Jesuit Volunteer Corps in Santa Rosa, our local Bishop (with whom I gave a co-homily and who was warm and charming when he had dinner with myself and fellow volunteers) had to resign over an embezzlement and extortion scandal involving a scorned male lover. Two pastors at my parents' local church had to resign for undisclosed reasons. My time at Boston College coincided with the Cardinal Law debacles and protests, and since moving to Dublin, Ireland in 2004, Church scandals from rampant child abuse and pedophilia (with pernicious cover-ups), the Magdalene Laundries and other stateChurch collusion and soul-destroying moral failures have been a ubiquitous and devastating feature. ${ }^{18}$ The death of the Irish Catholic Church is often mentioned in the Irish press, and even in homilies, though with the hope that a kinder, more compassionate, and lay-led Church will rise in its wake. ${ }^{19}$ This is the reality of the Church I matured into as a student, then teacher, father, and scholar. While Vatican II may have formed many Catholics in the 1970s and 1980s, these Church scandals, sadly, have deeply informed my mature Catholic outlook. What post-Shoah soul searching was for the generation of Metz, the child abuse scandal is for many younger Catholics, especially those in their 20 s and 30 s. I place myself (in my early 40s) in the middle, hemmed in by Metz's call for a Church to reckon with its past

\footnotetext{
${ }^{18}$ See, for example, Fr. Tony Flannery, Responding to the Ryan Report (Dublin: Columba, 2009); Maeve Lewis, "Vatican meeting shows a church incapable of holding itself to account," The Irish Times (1 March 2019), https://www.irishtimes.com/opinion/vatican-meeting-shows-a-church-incapable-ofholding-itself-to-account-1.3810159; and my "The Pedophile Scandal and Its (Hoped-for) Impact on Catholic Intra- and Interreligious Dialogue," in Loss and Hope: Global, Interreligious, and Interdisciplinary Perspectives, ed. Peter Admirand (London: Bloomsbury, 2014), 123-36.

${ }^{19}$ Father Joe McDonald, for example, published a book, Why the Irish Church Deserves to Die (Dublin: Columba Press, 2017). Recently, he gave the homily at our Catholic Church (19 November 2019) in Rathmines, echoing the statement above but deeply hopeful of a more loving, reborn church.
} 
sins (especially in the Shoah) and on the other side by the child abuse crisis that speaks of both past and present Church failures towards its own members. Except for a besieged, defensive mentality, the only other options are to leave the Church (which many are doing) or believe with a deeply humbled, interfaith (if not pluralist) outlook. ${ }^{20}$

As a supporter of liberation theology, ${ }^{21}$ I wanted to cry when Joseph Ratzinger succeeded John Paul II as pope. During those dark times, anyone genuinely interested in liberation theology, interfaith dialogue, religious pluralism, feminism, the secular-religious dialogue and partnership (or those like me who embrace them all but needed to find a stable theology job in the midst of the great recession), had to code statements and stifle real questions and views - or someone might challenge your Catholic identity. They would care little that you brought your young children to the church every Sunday and had a kind of stubborn love for the institutional Church that as the People of God, you could see as both beautiful and gracefuland frail, myopic, and misguided. When I voiced this at an academic conference, evaluating John Paul's "mixed" legacy on interreligious dialogue, a "holy," doubtfree Catholic, with saliva on his enraged mouth, questioned whether I was a true Catholic. This scholar had invited me to talk amidst a number of papal representatives, thinking I would just sing the deceased pope's praises. ${ }^{22}$

My first book was on theodicy, especially grappling with memoirs and witness testimony from the Shoah, killing fields, gulags, and dirty wars. This work not only humbled theistic faith but all aspects of religious, communal, and institutional belonging. With a fractured faith (built on a fractured theodicy), I still, however, believed, participated, taught, and witnessed my Catholic identity. When Pope Francis was elected, I was initially skeptical in light of claims made about him during and after Argentina's Dirty War which survivor Alicia Partnoy calls a genocide. ${ }^{23} \mathrm{I}$ feared another instance of elite men in the institutional church placing sacramental access and institutional survival ahead of a deep and unyielding solidarity to the poor, the accused, the broken, and the outcast. ${ }^{24}$ Pope Francis has surprised and enlightened me in many ways, though some questions about the Catholic Church's role during the government dictatorship in Argentina-among other places - remain alive and in need of full outside evaluation.

A few more self-indulgent paragraphs: I have five children, currently ranging in age from 5 to 17 . The oldest ones have already seen the dying, if not death, of the church, the hypocrisies, the silencing of devoted people. They have heard the

\footnotetext{
${ }^{20}$ This is one of my core arguments in Humbling Faith.

${ }^{21}$ See, for example, my "Why Liberation Theology Should Be Taught in Catholic Secondary Schools." International Studies in Catholic Education 10 (2018): 156-69.

${ }^{22}$ See my "Rifts, Trust, and Openness: John Paul II's Legacy in Catholic Intra-and-Interreligious Dialogue," Journal of Ecumenical Studies 47 (Fall 2012): 555-75.

${ }^{23}$ See Alicia Partnoy, The Little School: Tales of Disappearance and Survival, trans. Lois Athey and Sandra Blaustein (San Francisco: Cleis, 1986).

${ }^{24}$ See, for example, my "How Pope Francis Can Purify the Church Despite a Dirty War," SEARCH: A Church of Ireland Journal 36 (Autumn 2013):163-78.
} 
crying of their mother when the church community we helped build was indifferently and tactically quashed because the new pastor, a published novelist who can give theologically-rich homilies, simply did not like children and wanted no children (like my very talented daughter) leading the Church in singing the Our Father; or, God forbid, the little ones would wander out of the pew and up on the altar before I could grab them; or I would have to hold the baby while reading the prayers of the faithful (which I had also written), because she would scream otherwise.

The pastor removed the professional and child-friendly leader of song; he made sure the wonderful Jesuit priest who came to the parish to do the family mass no longer felt as welcome; and he bullied family mass members he could speak to alone to get his point across. He stayed far away from me after our first - and with him, last-family mass meeting where he promised changes in the future but heard my kind, yet firm account of the history of our group which he was now joining. It was a losing battle, though. He curtly dismissed a 75-year-old widow who devoted most of her week to planning for the family mass, preparing balloons or other props for the children, along with crayons and food. With tears in her eyes, she left, and has never returned. The sacristan, who seemed to spend every minute of his spare time making sure church life was vibrant, was also made to feel unwelcome, and so after years of service, he resigned. No public mention was made of his work or dedication. I tried to fight this with various appeals, but as a fellow colleague and priest told me, "Pastors are invincible. Just go to a different church."

Yet, it was the church my kids grew up in. They wanted to stay, so with the family mass virtually ended, we went to the more popular 6 PM folk mass, a wellknown "institution" in Ireland, at the same church. The pastor also tried to bully the folk mass leader, but Kevin replied, "Any other church will gladly take us in after our forty years plus of history..." so the pastor pulled back. The folk mass usually brings in guest presiders, amazing priests who dedicate their lives to the poor like Peter McVerry, or who prophecy deep and radical church reform. Two of the priests, while in seminary, had been sexually abused by senior clergy, so when they talk about the child abuse cover up and scandal, there is a heartfelt authenticity and gravitas to their words and proclamations. One of my sons, who had been an altar server at the family mass, agreed to serve at the 6 PM masses so long as the pastor was not there. Every Sunday we would first check to see who was presiding. My kids had felt the cold stares and angry, blatant glances at them. Trying to defend the church felt impossible. They lived and saw the corruption, and I, a Catholic theologian, can no longer stomach trying to bribe or force the older boys to go to mass. I cannot be mad at them; their reactions are understandable.

I therefore enter Berger and Patterson's question with deep spiritual brokenness, humility, and pain, but also hope and longing. To pretend otherwise is to do the question, and my faith, no justice.

\section{On Recent Developments in Jewish-Christian Relations}

Like Virgil's Aeneid, I will go en medias res here in this section, with a quick review of some seminal developments in Christian-Jewish relations, and especially 
the Catholic Church's evolving institutional views on Judaism. Some of the key breadcrumbs here include: Jesus' Jewishness, which as Nostra Aetate 4 proclaims, should be celebrated and studied, as should the Jewish roots of many of Jesus' early followers and family ${ }^{25}$; so, too should Christians respect and learn Jewish ways of reading the Tanach, which are also valid ${ }^{26}$; and rejoice in the ongoing, rich and diverse life of the Jewish people, as still beloved of God (not replaced as supersessionism would contend ${ }^{27}$ ); the Jews, moreover, are the biblical people whose covenant is alive and vibrant, irrevocable, who cannot be blamed for the death of Jesus, and most importantly, for whom no systematic, institutional attempt to convert should be undertaken by the Catholic Church.

These are some of the key theological crumbs; the other ones are sprinkledor dolloped - in the autobiographical section above, namely: the human, ordinary holiness within and among my Jewish friends, neighbors and teammates; the wellnoted deep moral frailty, failures and sinfulness of the Catholic Church (the latter

\footnotetext{
${ }^{25}$ For a recent and lively historical account, see Paula Fredriksen, When Christians Were Jews: The First Generation (New Haven: Yale University Press, 2019); and the review by Philip Cunningham in Studies in Christian-Jewish Relations 14 (2019):1-4, https://ejournals.bc.edu/index.php/scjr/article/view/11005/9363.

${ }^{26}$ Helpful here is the Pontifical Biblical Commission, "The Jewish People and their Sacred Scriptures in the Christian Bible" (24 May 2001). Consider, for example, $\$ 87$, naming and cautioning about passages in the New Testament that could and have been used against Jews: "But it must be admitted that many of these passages are capable of providing a pretext for anti-Jewish sentiment and have in fact been used in this way. To avoid mistakes of this kind, it must be kept in mind that the New Testament polemical texts, even those expressed in general terms, have to do with concrete historical contexts and are never meant to be applied to Jews of all times and places merely because they are Jews." http://www.vatican.va/roman_curia/congregations/cfaith/pcb_documents/rc_con_cfaith_doc_20020212_popolo-ebraico_en.html.

${ }^{27}$ Jewish theologian Adam Gregerman, for example, rightly notes how a Catholic sense of superiority can remain even when supersessionism is supposedly rejected. See his "Superiority without Supersessionism: Walter Kasper and The Gifts and the Calling of God are Irrevocable on the Status of God's Covenant with the Jews after Jesus," Theological Studies 79 (2018): 36-59. My position here removes any doubt of the theological viability of supersessionism or religious superiority for Catholics, so there is not even what Gregerman discusses as "good" or "better" covenants, just flawed, broken, humbled, seeking-the-good-covenants.
} 
in stark disagreement to the approach approved by John Paul II in "We Remember" 28 ); and the burgeoning reality of religious pluralism, ${ }^{29}$ which does not merely evince the fact of religious diversity but testifies to good, holy people living Christlike lives. Such are lives of compassion, kindness, and solidarity with the poor and oppressed, challenging institutional injustice, structural sin, gender discrimination (among other kinds), and (with the help of indigenous groups, and more recently Laudato $\mathrm{Si}$ ), ecological destruction. ${ }^{30}$

Building upon Nostra Aetate's call to study and respect other faiths, particularly Judaism, has only been a spiritual and moral boon and aid for Christians. Christians have benefitted from being exposed to: the acute nuance, humor, and moral thrust of rabbinic writings and biblical interpretation ${ }^{31}$; the depth and mystery of Kabbalah ${ }^{32}$; holy envy ${ }^{33}$ when participating in Jewish festivals and rituals ${ }^{34}$;

\footnotetext{
28 "We Remember: A Reflection on the Shoah" was published in 1998 by the Catholic Commission for Religious Relations with the Jews, along with a prefatory letter from John Paul II, http://www.vatican.va/roman curia/pontifical councils/chrstuni/documents/rc pe chrstuni doc 16031998 shoah en html. The reflection's approach, approved by John Paul II and endorsed by then Cardinal Joseph Ratzinger, is to demarcate and so elevate the Mystical Body of Christ (following the writings of Pius XII) from those Christians who failed to listen and heed Church teaching. Thus, the Church's essence, is linked to but cannot be adulterated by human individuals in the Church who commit sins and hypocrisy. The Church itself thus remains sinless. It is not, therefore, the Universal Church, the one holy apostolic Church, who is accountable or should repent and ask for forgiveness for crimes committed by lay and clergy members of the Church. This distinction is rarely deemed acceptable by victims, and that in itself demands a different, or better, explanation. See, for example, the editorial "Asking Forgiveness" in America (25 March 2000), https://www.americamagazine.org/issue/281/editorial/askingforgiveness.

${ }^{29}$ See, for example, Perry Schmidt Leukel, Religious Pluralism and Interreligious Theology: The Gifford Lectures-An Extended Edition (Maryknoll: Orbis, 2017). For commentary on this text, see Paul Knitter and Alan Race, eds., New Paths for Interreligious Theology: Perry Schmidt-Leukel's Fractal Interpretation of Religious Diversity (Maryknoll: Orbis, 2019). For my survey of religious pluralism, see Humbling Faith, chapter 3.

${ }^{30}$ It is somewhat of a stretch to cite Jesus as an eco-trail blazer as does Pope Francis, Laudato Si (May 2015), §98, where "Jesus lived in full harmony with creation." Amos Oz reminds us of Jesus' problematic cursing of the fig tree in his Judas (London: Vintage, 2016), 244. See also Sarvepalli Radhakrisnan's critique, examined in R.S. Sugirtharajah, Jesus in Asia (Cambridge, MA: Harvard University Press, 2018), 181-182. Regardless, Pope Francis' Laudato Si is waking the global Catholic Church up to the dire truths of climate change and ecological destruction (http://w2.vatican.va/content/francesco/en/encyclicals/documents/papa-francesco_20150524 enciclica-laudato-si.html).

${ }^{31}$ See, for example, Norman Solomon, editor and translator, The Talmud: A Selection (London: Penguin, 2009); Charlotte E. Fonrobert and Martin S. Jaffee, eds., The Cambridge Companion to the Talmud and Rabbinic Literature (Cambridge, UK: Cambridge University Press, 2007); Elie Wiesel, Wise Men and Their Tales: Portraits of Biblical, Talmudic, and Hasidic Masters (New York: Schocken, 2003); and Emmanuel Lévinas, Beyond the Verse: Talmudic Readings and Lectures, trans. Gary D. Mole (London: Continuum, 2007).

${ }^{32}$ Alan Unterman, ed. and trans., The Kabbalistic Tradition (London: Penguin, 2008).

${ }^{33}$ Hans Gustafson, ed., Learning from Other Religious Traditions: Leaving Room for Holy Envy (Cham, Switzerland: Palgrave Macmillan, 2018).

${ }^{34}$ A good overall resource is George Robinson, Essential Judaism, Updated Edition: A Complete Guide to Beliefs, Customs \& Rituals (New York: Atria Books, 2016).
} 
the profound and challenging diversity of post-Shoah Jewish theology and philosophy ${ }^{35}$; and the liberal generosity and trust shown by Jewish people, books, and texts $^{36}$ testifying to and praising Christians for deep changes since the Shoah, from "Dabru Emet" anity." ${ }^{38}$ I would also be remiss if I did not mention the warmth and acceptance of the Irish Jewish community, and especially the Jewish members in the Irish and the International Council of Christians and Jews.

\section{Peter Phan's Interfaith Christology}

Where should and does this lead us? Many readers may know the paths that have traditionally brought down the CDF's ire and condemnation, especially any explicit support of salvific ways outside the sacramental Church. The stories of theologians like Jacques Dupuis, Jon Sobrino, and Elizabeth Johnson are wellknown in Catholic theological circles. ${ }^{39}$ With roads advocating a movement beyond the inclusivist ${ }^{40}$ approach to religious plurality blocked, some try alternative methods or half-measures, usually out of fear and the desire to avoid losing the label or job title as Catholic theologian. Many perhaps follow then Cardinal Ratzinger's approach and say let us delay such discussions (of Judaism and salvation) until the Second Coming. ${ }^{41}$ I think such delay is a missed opportunity; an attempt to answer the question shows greater respect towards Jesus' life as a faithful Jew.

As one way forward, consider the case of Vietnamese and American Catholic theologian, Peter Phan. His Being Religious Interreligiously was investigated by the Committee on Doctrine. The process began officially for Phan with a letter

\footnotetext{
${ }^{35}$ See especially Steven T. Katz, Shlomo Biderman, and Gershon Greenberg, eds., Wrestling with God: Jewish Theological Responses during and after the Holocaust (Oxford: Oxford University Press, 2007). For my analysis, see Amidst Mass Atrocity, chapters 6-7.

${ }^{36}$ See, for example, Amy-Jill Levine and Marc Zvi Brettler, eds., The Jewish Annotated New Testament, $2^{\text {nd }}$ Edition (Oxford: Oxford University Press, 2017); and Debbie Weissman, Memoirs of a Hopeful Pessimist: A Life of Activism through Dialogue (Jerusalem: Ktav, 2017).

${ }^{37}$ Dabru Emet: A Jewish Statement on Christians and Christianity, Institute for Islamic-Christian-Jewish Studies (September 10, 2000), https://icjs.org/resources/dabru-emet.

38 "Orthodox Rabbinic Statement on Christianity: To Do the Will of Our Father in Heaven: Toward a Partnership between Jews and Christians," The Center for Jewish-Christian Understanding and Cooperation (December 3, 2015), http://cjcuc.com/site/2015/12/03/orthodox-rabbinic-statement-onchristianity/.

${ }^{39}$ See, for example, William R. Burrows, Jacques Dupuis Faces the Inquisition: Two Essays by Jacques Dupuis on Dominus Iesus and the Roman Investigation of His Work (Eugene, OR: Pickwick, 2012).

${ }^{40}$ The Catholic Church's position, post Vatican-II, can be described as inclusivist. NA disavowed exclusivism, especially a phrase like "outside the Church there is no salvation." Christian inclusivism maintains ultimate salvation is through the life, death, and resurrection of Jesus and in the sacramental life of the Church founded by Christ. The Church also recognizes those acts, beliefs, and ways in other faiths that are holy, though they are not vehicles of salvation in themselves. Those religions are partially, not fully true. See David Cheetham, "Inclusivisms: Honouring Faithfulness and Openness," in Christian Approaches to Other Faiths, ed., Alan Race and Paul Hedges (London: SCM Press, 2008), 63-84. ${ }^{41}$ See his essays in Joseph Ratzinger, Pilgrim Fellowship of Faith. The Church as Communion, trans. Henry Taylor (San Francisco: Ignatius Press, 2005).
} 
from the Congregation for the Doctrine of the Faith in July 2005, initiated, he believes, while Ratzinger was still prefect and so before William Levada succeeded him and Ratzinger became pope. ${ }^{42}$ With frequent citations from Dominus Iesus,${ }^{43}$ the committee cited "ambiguities and equivocations" in Phan's Being Religious Interreligiously, that without proper clarifications, were not "in accord with Catholic teaching." The Committee concluded the note by stating that they are obliged as bishops to "ensure that the singularity of Jesus and the Church be perceived in all clarity and the universal significance be acknowledged in the fullness of truth." 44

As recounted in his The Joy of Religious Pluralism, Phan's approach to such accusations was one of coy delay and careful replies. Phan cited his very busy publication, speaking, and teaching load, and with an eye to the justice of the proceedings, he asked for financial compensation to cover any leave from work that would be required to craft a response. He clarified that as a priest he did not need any money, but worried about the precedent if a lay theologian with a family were given a similar ultimatum. Phan, though, never fully responded to the CDF, who tried to curb his future publishing. Instead, in his 2017 book, The Joy of Religious Pluralism: A Personal Journey, he published an account of the notifications and an initial apologia for his position. He chose to do this because of Pope Benedict's resignation and the election of Francis. ${ }^{45}$ It is fascinating that Phan's book has received little to no public Vatican response. On the surface at least, Phan delayed a direct response to the Vatican and then replied very publicly.

In this later book, Phan sketches out an interfaith Christology and describes the celebration or joy of religious pluralism. Interfaith Christology, which is part of a deeper awareness and need to do all our theology outside of a closed, insular church, recognizes that we more than ever live in a global, interconnected world. His Christology is not simply the study of Christ though gospel texts and epistles, a typological reading of the "Old Testament," the commentaries of Church Fathers, and various Vatican decrees. Rather, he expands Christology's interpretations to include those from all the world's faiths. Such inclusion is not because the view of a Buddhist or atheist about Jesus supersedes the Jesus of, for example Pope Benedict's books. ${ }^{46}$ Phan believes Jesus as God Incarnate is best expressed through a

\footnotetext{
${ }^{42}$ Phan, Joy of Religious Pluralism, 2-3.

${ }^{43}$ The best multi-authored account of Dominus Iesus remains Stephen L. Pope and Charles Hefling, eds., Sic et Non: Encountering Dominus Iesus (Maryknoll, NY: Orbis, 2002).

${ }^{44}$ Quoted in Peter C. Phan, Being Religious Interreligiously: Asian Perspectives on Interfaith Dialogue (Maryknoll, NY: Orbis, 2004), 222.

${ }^{45}$ For a helpful interfaith assessment of Pope Francis' statements on interreligious dialogue, see Harold Kasimow and Alan Race, eds., Pope Francis and Interreligious Dialogue: Religious Thinkers Engage with Recent Papal Initiatives (Cham, Switzerland: Palgrave Macmillan, 2018).

${ }^{46}$ See especially, Benedict XVI (Joseph Ratzinger), Jesus of Nazareth: From the Baptism in the Jordan to the Transfiguration, trans. Adrian J. Walker (New York: Doubleday, 2007); and Jesus of Nazareth: Holy Week: From the Entrance into Jerusalem to the Resurrection, trans. Philip J. Whitmore (New York: Paulist, 2011). While also deserving of study, I would argue they are inordinately concerned with a Jesus establishing future Church doctrines and foundations. The strength of Phan's interfaith Christology is to expand the orbit of views, insights, and interpretations of Jesus. Christology would be lacking if Benedict's interpretations were absent, but they would be anemic if the only or privileged one. I've learned as much about Jesus from many Buddhists and Jews as I have from fellow Christians.
} 
universal and thus multi-faith and multicultural context. Developing such a Christology, according to Phan, should ideally involve "collaboration" between Christians and non-Christians. ${ }^{47}$ There are insights, questions, and challenges that non-Christians in particular bring to examining and interpreting the words and actions of Jesus, which are often unaddressed or differently evaluated by Christians.

Such an approach is also fruitful in the theological classroom. In my second year undergraduate Christology module at Dublin City University, my class studies Jewish, Muslim, Hindu, Buddhist, and indigenous views of Jesus, as well as portrayals of Jesus in film, global art, television, novels, and contemporary music, in addition to studies of the gospel, church fathers, theologians, councils, and Vatican documents. Before reading Phan, I never called this method an "interfaith Christology," but said, "No one owns Jesus" and if Jesus is truly God made flesh, a universal savior, it makes sense to reflect and learn how Jesus is interpreted and presented across all faiths and cultures. Such an approach also highlights how Christologies (like interpretations of God) often reflect individual and cultural identities and priorities. Such pluralist Christologies, of course, are rooted in plural conceptions of Jesus in the four gospels and Pauline epistles.

For Phan, interfaith Christology is "essentially a Spirit or pneumatological Christology consisting in an elaboration on the work of Jesus as the Christ by virtue of the Spirit in bringing about humanity's union with God and/or human self-realization." ${ }^{48}$ Much has been written about the overlooked Holy Spirit pre-Vatican II and the need to seek and praise the Spirit of God working beyond expected or named Church boundaries and jurisdictions. ${ }^{49}$ In essence, Phan asks us to take Trinitarian belief seriously. The one, all-encompassing creator God of love, uniquely and at one historic time only, became incarnate as Jesus of Nazareth. As importantly, Phan stresses how the spirit of God is also teeming and alive in all corners of our universe, reflected in all of creation, in all of life, and in a special way within human beings.

As an aside, here I would contend any uniqueness of humanity is rightfully challenged by fields like primatology and pachydermatology (study of elephants), and perhaps astrobiology and astrotheology. ${ }^{50}$ This truly cosmic sense of God entails a cosmic Christ, who cannot be disassociated from the finite few decades of human life lived by Jesus of Nazareth on this earth but acknowledges that the spirit of Christ, suffused in love of the broken and marginalized, in a sacrificial love seeking justice and solidarity, is present and embodied across space and time, regardless of whether the Jesus of the Gospels is explicitly named and known as such.

Phan argues that the "foundation stone" in theological explanation with, about, and to non-Christians, what we call interreligious dialogue, should be the Holy

\footnotetext{
${ }^{47}$ Phan, Joy of Religious Pluralism, 92.

${ }^{48}$ Phan, Joy of Religious Pluralism, 96.

${ }^{49}$ See, for example, the careful work of Dermot A. Lane, Stepping Stones to Other Religions: A Christian Theology of Interreligious Dialogue (Dublin: Veritas, 2011).

${ }^{50}$ See, for example, Peter M.J. Hess, "Multiple Incarnations of the One Christ," in Astrotheology: Science and Theology Meet Extraterrestrial Life, ed. Ted Peters, Martinez Hewlett, Joshua M. Moritz, and Robert John Russell (Eugene, OR: Cascade Books, 2018), 317-329.
} 
Spirit. ${ }^{51}$ The point is to see learning, salvific enlightenment, and relations as "reciprocal," and not uni-directional. ${ }^{52}$ Phan particularly challenges fulfilment theology, ${ }^{53}$ which (contra Gavin D'Costa ${ }^{54}$ ) is just a kinder and gentler form of supersessionism. Phan instead advocates a "kenotic theology of relations among religions," in which "Christianity humbly renounces its claim of 'unicity' and superiority over other religions." "55 I contend such is to live our institutional, doctrinal, and communal Catholic faith in Jesus' words: "So the last will be first, and the first will be last" (Matt 20:16).

So, too Phan prioritizes: wherever there is a conflict, the kingdom of God-and not the church-"[is] the ultimate mission." ${ }^{56}$ Such a path is particularly promising with Phan's suggested addition of two magisteria to Catholic teaching and learning; namely, a magisterium of the poor and a magisterium of non-Christian believers" which should join the established Episcopal, Theological, and Lay Magisteria. ${ }^{57}$

Other theologians contribute in various ways to this conversation. Felix Wilfred calls us to move beyond not only critiques of interreligious dialogue ${ }^{58}$ but also beyond seeing interreligious dialogue merely as a space between distinct beings, sects, and faiths. Wilfred pushes us to think in terms of cosmopolitanism. He contends that Christianity needs to practice "reverse universality" by being open to what he calls "incoming universality." ${ }^{59}$ Instead of Christianity containing all the truth and solely spreading this truth to make it universal, Christians need to be ever more attuned and open to the challenges and truths of other faiths and paths. $\mathrm{He}$ thus calls for a rootedness and detachment from one's religion so that the goodness and universal love of God can be seen as truly spread through time and creation.

John Thatamanil, similarly calls for the Church to overcome its ethos of religious self-sufficiency and to recognize a deeper sense of interreligious learning. Imagining he had an opportunity to revise and update Nostra Aetate, he adds the phrase that love of Jesus compels the church to "receive truth and wisdom from those outside the church," an idea undeveloped in the 1965 seminal document. Thatamanil also would have NA reference the Wisdom of the First Nations and

\footnotetext{
${ }^{51}$ Phan, Joy of Religious Pluralism, 51.

${ }^{52}$ Phan, Joy of Religious Pluralism, 111.

${ }^{53}$ Phan, Joy of Religious Pluralism, 115.

${ }^{54}$ See Gavin D’Costa, “Supersessionism: Harsh, Mild or Gone For Good?" European Judaism 50, no. 1 (Spring 2017): 99-107; see also Gavin D’Costa, Paul F. Knitter, and Daniel Strange, Only One Way?: Three Christian Responses to the Uniqueness of Christ in a Religiously Pluralist World (London: SCM, 2011); and Gavin D'Costa, Catholic Doctrines on the Jewish People after Vatican II (Oxford: Oxford University Press, 2019).

${ }^{55}$ Phan, Joy of Religious Pluralism, 118-119. See also Paul F. Knitter, ed., The Myth of Religious Superiority: A Multifaith Exploration (Maryknoll, NY: Orbis, 2005).

${ }^{56}$ Phan, Joy of Religious Pluralism, 156.

${ }^{57}$ Phan, Joy of Religious Pluralism, 42.

${ }^{58}$ For such critiques, see Muthuraj Swamy, The Problem with Interreligious Dialogue: Plurality, Conflict and Elitism in Hindu-Christian-Muslim Relations (London: Bloomsbury, 2016).

${ }^{59}$ Felix Wilfred, "From Inter-religious Dialogue to Religious Cosmopolitanism," in The Past, Present, and Future of Theologies of Interreligious Dialogue, ed. Terrence Merrigan and John Friday (Oxford University Press, 2017), 216-232.
} 
expand and nuance Nostra Aetate's positive statements on Hinduism and Buddhism. ${ }^{60}$

Paul Knitter, like Thatamanil and Phan, challenges Nostra Aetate's sense of "religious supremacy" and calls the Church (with Pope Francis as a guide) to follow a green dialogue, partnering and focusing on how to restore and save the health of the earth, without being mired in theological squabbles. ${ }^{61} \mathrm{John}$ Pawlikowski, moreover, advocates a non-supersessionist incarnational Christology and bravely warns against letting Jesus' singular uniqueness stymie the idea of God within all of us and within all of creation. He calls for allowing such ideas to percolate our theological thinking. ${ }^{62}$ A similar openness courses through Roger Haight's contention that a Christian spirituality should "respect and promote pluralism." 63

Another key theological breadcrumb is Pope Francis' ongoing relationship with Judaism, exemplified in his friendship, respect, and co-authorship with Rabbi Abraham Skorka. ${ }^{64}$ Francis can still sometimes slip into supersessionist language and be uncritical of anti-Pharisaic tropes in the Gospels; however, his repeated praise and practice of interfaith dialogue and his friendship and professional history with Rabbi Skorka speak more than any document or dogma. Bergoglio and Skorka are two holy men trying to do the will of God, seeking the good, hoping to lead others to that good, learning and dialoguing with one another, and never attempting to convert the other. Such is the essence of a Catholic relationship with the sanctity, links, and distinctiveness of Judaism.

\section{On Jesus' “Superfluous," Salvific Gift}

While the advances in Jewish-Christian relations are laudatory, some Christians may wonder: What about the purpose of Jesus' life and death and the question of salvation? What about the emphasis in Dominus Iesus on Jesus as the sole,

\footnotetext{
${ }^{60}$ John J. Thatamanil, "Learning from (and Not Just about) Our Religious Neighbors:

Comparative Theology and the Future of Nostra Aetate," in The Future of Interreligious Dialogue: A Multireligious Conversation on "Nostra Aetate," ed. Charles L. Cohen, Paul F. Knitter, and Ulrich Rosenhagen (Maryknoll, NY: Orbis, 2017), 289-301. See also his Circling the Elephant: A Comparative Theology of Religious Diversity (New York: Fordham, 2020).

${ }^{61}$ Paul Knitter, "Nostra Aetate: A Milestone in the History of Religions? From Competition to Cooperation," in The Future of Interreligious Dialogue: A Multireligious Conversation on "Nostra Aetate," ed. Charles L. Cohen, Paul F. Knitter, and Ulrich Rosenhagen (Maryknoll, NY: Orbis, 2017), 50; and especially his Without Buddha I Could not be a Christian (London: Oneworld, 2017).

${ }^{62}$ John T. Pawlikowski, "Toward a Renewed Theology of Christianity's Bond with Judaism," in The Future of Interreligious Dialogue: A Multireligious Conversation on "Nostra Aetate," ed. Charles L. Cohen, Paul F. Knitter, and Ulrich Rosenhagen (Maryknoll, NY: Orbis, 2017), 85. See also Elena G. Procario-Foley and Robert A. Cathey, eds., Righting Relations after the Holocaust and Vatican II: Essays in Honor of John Pawlikowski, OSM (Mahweh, NJ: Paulist Press, 2018).

${ }^{63}$ Roger Haight, "The Christian Spiritual Vision from the Perspective of Nostra Aetate," in The Future of Interreligious Dialogue: A Multireligious Conversation on "Nostra Aetate," ed. Charles L. Cohen, Paul F. Knitter, and Ulrich Rosenhagen (Maryknoll, NY: Orbis, 2017), 94. See also Roger Haight, The Future of Christology (New York: Continuum, 2007).

${ }^{64}$ See, for example, Jorge Mario Bergoglio and Abraham Skorka, On Heaven and Earth: Pope Francis on Faith, Family and the Church in the Twenty-first Century (New York: Image, 2013).
} 
unique, and universal savior of the world? Does not a full openness to the salvific integrity of Judaism undermine, if not annul, belief in Christ? How can both ways be viable? As noted, the Vatican (especially in the writings of Ratzinger) has instructed believers to delay this question of the salvation of the Jews until Jesus' second coming. Until then, Jews and Christians should continue on their distinctive, though biblically linked paths. I believe another way is more spiritually and theologically fruitful, though it comes with its own challenges. Consider, for example, Christology in the Franciscan tradition, especially as presented by Richard Rohr, who draws upon John Duns Scotus. ${ }^{65}$ Rohr emphasizes how this tradition explains that Jesus' death on the cross was not because God demanded a blood sacrifice, but because a life in solidarity with the poor and outcast often leads to the cross, as Martin Luther King Jr. or Oscar Romero and others witness. Jesus came into the world to further testify to the love of God and one another as the biblical prophets decreed. Sometimes, such love demands sacrifice or suffering for others (John 15:13). Jesus' death on the cross was a profound sign of God's love of humanity. Contra an Origen, Anselm, or Athanasius, the cross was not a part of God's plan to trick any devil, overcome original sin regarding any piece of fruit in a mythological garden, or appease a wrathful, numbers-crunching deity.

This interpretation, which I will expand below, can seem to challenge and undermine a book's worth of scriptural, theological, and doctrinal statements. There is no denying that a major thread runs through New Testament Christology of a Jesus who died for the sins of humanity, as a sacrifice, a paschal lamb, or as Mark notes, a Son of Man, who came to serve and "to give his life a ransom for many" (Mark 10:45; see also Matt 20:28). John 3:16 may be the most ubiquitous Gospel quote: "For God so loved the world that he gave his only Son, so that everyone who believes in him may not perish but may have eternal life." Among the letters most likely written by Paul, we read: "But God proves his love for us in that while we still were sinners Christ died for us" (Rom 5:8); "who, though he was in the form of God, did not regard equality with God as something to be exploited, but emptied himself, taking the form of a slave, being born in human likeness. And being found in human form, he humbled himself and became obedient to the point of deatheven death on a cross" (Phil 2:6-8); and "I have been crucified with Christ; and it is no longer I who live, but it is Christ who lives in me. And the life I now live in the flesh I live by faith in the Son of God, who loved me and gave himself for me" (Gal 2:19-20). The literal meaning of these verses seems fairly united and clear.

The liturgy reinforces this. The priest echoes the words of John the Baptist as he holds up the sacred host: "Behold, the Lamb of God, who takes away the sin of the world!" (John 1:29). All Catholics profess the Creed at mass, including the phrase: "For our sake he was crucified under Pontius Pilate; he suffered death and was buried." This standard story is buttressed in classical texts like Athanasius's De Incarnatione Verbi Dei or Anselm's Cur deus homo, among many others. This

\footnotetext{
${ }^{65}$ See Richard Rohr, "The Franciscan Option," in Stricken by God? Nonviolent Identification and the Victory of Christ, ed. Brad Jersak and Michael Hardin (Grand Rapids: Eerdmans, 2007), 206-12. I also thank an anonymous reviewer for challenging me to expand more on my theological argument, especially regarding "the salvific efficacy of Christ."
} 
theme is foundational to Catholic salvific understanding and identity, and again, is at the root of why Jesus is argued to be the one and only, unique, universal savior of the world. It is on account of such a sacrifice-for the sins of the world - that Jesus cannot be equated with the Buddha, and why Quranic claims of Prophet Muhammad as "the seal of the prophets," or which categorize Jesus as special, but still only one of many prophets, are rejected by the Church. Jesus alone is God incarnate which is why his murder on the cross is of such universal and timeless relevance.

\section{More Difficult Questions}

My contribution to this conversation is that Christianity's inordinate focus on trying to uphold this narrative of sin and sacrifice has failed to present, and more importantly, to live out the love of Christ. Excessive focus on Jesus' salvific uniqueness has led to downplaying or dismissing other holy ways of life, most pertinently here, of Judaism. It has contributed to (or at least not sufficiently countered) much of the anti-Judaism sinfully heaped upon the Jewish people by Christians. In addition, this explanation of why Jesus had to be sacrificed leads to an excessive denigration of humanity as sinful, claiming that we were no different from the humans at the time of the mythical flood. Therefore, without Jesus's sacrifice, we were all destined to perdition. This stark language generates a requirement of some divine action to overcome original sin or Adam's fall and is difficult to support today. The idea of tainted humanity with babies born in sin is a pernicious view, never embraced by Jews and Muslims. Such a narrative of God's demanding sacrifice and blood remains perplexing, if not morally repugnant to many of us today. God, after all, stopped such a useless sacrifice on Mount Moriah. How can Jesus be a second Isaac? This telling, moreover, also makes little sense scientifically in light of irrefutable proof that the already morally problematic myth of the garden of Eden story ${ }^{66}$ is a rich and valuable tale, but only a tale. ${ }^{67}$

Could seeing Jesus' life and death instead as a free, unmerited, almost superfluous act ironically render it all the more noble, inspiring, and holy? Perhaps, what is most extraordinary about Jesus' death on the cross is precisely that it was not necessary in terms of the salvation of all, though it clearly has guided a moral way of life for billions. The Christian belief in Jesus' resurrection also signals both hope in an afterlife context and, more importantly, the demand for justice in a world where genocides and atrocities are met with impunity or silence.

\footnotetext{
${ }^{66}$ While "willful ignorance" was condemned by the Greeks, moral responsibility is dependent upon awareness and maturity of the thoughts, words, deeds, intentions, and likely consequences of our actions. It is difficult to attribute any high levels of such moral cognition to Adam, and especially to Eve (as the biblical text never reveals God explaining the rules to her). More problematically, our humanity is based on our finite struggles to seek and know what is good, in the context of being free within the restrictions and limitations of our finitude. Eating of the tree of good and evil would seem necessary, then, for us to be fully human. If so, is (some) disobedience of God needed to be fully human?

${ }^{67}$ For helpful analysis, see for example, James Kugel: How to Read the Bible: A Guide to Scripture, Then and Now (New York: Free Press, 2007), 47-57.
} 
If this means that God's path for humanity was already clear and known, was Jesus' entire life, then, theologically superfluous? This seems to be the more important question if I want to state that the Jewish way of life in itself is salvific, that Jews (like Jesus) learned the core moral truths of love of God and love of neighbor in Jewish Scripture. Such would seem to imply it was not fundamentally essential for Jesus to come into the world and show (at least) his fellow Jews the way.

Again, such a Christology would stress that Jesus came freely and without both obligation or salvific requirement to redeem the world. He inspired as many people as he could to turn to God, challenging and refining previous truths, extending the circle of all who are called (here one could talk about a needed, required way), trying to spread the community of God to the far reaches of the earth. As noted, this moral and social justice calling often comes with a price, but Jesus was willing to make that sacrifice, even if it could be dismissed as useless, excessive, or superfluous. Jesus wanted to remind some, and show others, of a God-infused life.

Why the majority of Jews rejected Jesus remains an uncomfortable question. At best, was he just a "failed," not a "false Messiah," as Irving Greenberg has argued? Was his calling to followers a subtle one, as Greenberg also wonders, or was it ultimately directed at Gentiles, as Michael Kogan contends? $?^{68}$

Finally, would any humbling of Jesus' universal salvific role have prevented Christian triumphalism against the Jewish people, let alone against indigenous groups and others? Does such humbling dilute or purify contemporary Christian identity, belief, and morality? Can Christians unequivocally accept the Jewish way of life as salvifically viable?

Such a yes to Judaism would move Catholic Christians beyond the inclusivist theology of Vatican II and firmly plant them in the exciting, but confusing area of a "principled" religious pluralism, to borrow from Irving Greenberg. ${ }^{69}$ Such pluralism is open, celebrating multiple paths to salvation within Judaism and Christianity, while maintaining differences and the core moral requirements of each. Can Catholic Christians really cross such a Rubicon?

\footnotetext{
${ }^{68}$ On Jesus as a false not failed Messiah, see Irving Greenberg, For the Sake of Heaven and Earth: The New Encounter between Judaism and Christianity (Philadelphia: Jewish Publication Society, 2004), 145-161; and for his comment: "that the resurrection signal had to be so marginal, so subject to alternate interpretations, and the incarnation sign so subtle, as to be able to be heard in dramatically opposing fashions," see p. 194. On Jesus coming predominantly for Gentiles, see Michael S. Kogan, Opening the Covenant: A Jewish Theology of Christianity (Oxford: Oxford University Press, 2008), 149. In the gospels, Jesus is portrayed as thinking his primary and priority mission is to the Jews. Encounters like the one with the Syrophoencian woman, seem to change that. See, for example, my "Traversing Towards the Other (Mark 7:24-30): The Syrophoenician Woman Amidst Voicelessness and Loss" in The Bible: Culture, Community, and Society, ed. Angus Paddison and Neil Messer (London: T \& T Clark International, 2013), 157-170.

${ }^{69}$ Greenberg, For the Sake, 208.
} 


\section{Conclusion: For our Children}

Biblically, the Rubicon was crossed long ago, not with the claims of John Hick and Paul Knitter in the now classic 1985 book resulting from their so-called "Rubicon conference," ${ }^{70}$ but when Jesus, told there was someone outside their circle doing miracles in his name, wisely said, "whoever is not against us is for us" (Mark 9:38). We have been against ourselves for too long, obsessing over boundary markers, purity, and yes, singularity, uniqueness, and universality. If we praise the Jewish life embodied ${ }^{71}$ and followed by Jesus; if Catholics call the Jewish people beloved of God, acknowledge their irrevocable covenant and make no sustained attempt to convert them, leaving things to some nebulous, purported second coming of the future, then we Catholic Christians seem to imply the Jewish way, too, is endorsed and beloved of God. We hesitate to go further, often out of fear, but the dots and breadcrumbs lead us to a fairly well-formed conclusion.

I return to Berger and Patterson's question: Is Jesus superfluous to salvation for Jews? Out of loyalty and deep love and respect for Jesus' life, death, and resurrection, we Christians have mostly clung to an adamant insistence that Jews too need Jesus. And yet, the murky, mythical haze of the two creation stories of Genesis now firmly sit alongside our deeper awareness of Darwinian evolution and creation over a span of billions of years. Of course, who can deny the existence of $\sin ^{72}$ in our fractured, broken, but still important to add, miraculously beautiful, overflowing-with-joy, world? We, however, and certainly our children, should no longer sincerely and unquestioningly speak of blood guilt and demanded sacrifice. Jesus, it should be remembered, transcends any meaning of the crucifixion, just as all victims transcend their victimhood and the violence unleashed against them.

Such statements do not then mean that I now echo Paul: "O, Death, where is your sting?" (1 Corinthians 15:55). Why? Because despite Jesus' murder and resurrection, death should still haunt us. The murdered victims of Auschwitz and Treblinka should eternally unsettle us; as should Little Eleanora, who perished in the Gulags of the Soviet Union. ${ }^{73}$ We should be ashamed and silenced at the brutal torture and death of the pregnant Ernestine Kaneza in the Rwandan genocide, as recounted in Jean Hatzfeld's most recent report, Blood Papa ${ }^{74}$ If we need to peer at so called natural evil, of "landscapes of loss" 75 and the billions murdered under an indifferent sky, we can also intone other names. Any Christian proclamation of

\footnotetext{
${ }^{70}$ The Myth of Christian Uniqueness: Toward a Pluralistic Theology of Religions, ed. Paul F. Knitter and John Hick (Maryknoll: Orbis, 1987).

${ }^{71}$ See, for example, Jacob Neusner, A Rabbi Talks with Jesus, rev. ed. (Montreal: McGill-Queen's University Press, 2007); and Edward Kessler, Jesus: Pocket Giants (Stroud, UK: History Press, 2016).

${ }^{72}$ Gary A. Anderson, Sin: A History (New Haven: Yale University Press, 2009).

${ }^{73}$ Anne Applebaum, Gulag: A History (New York: Anchor, 2003), 320-21.

${ }^{74}$ Jean Hatzfeld, Blood Papa: Rwanda's New Generation, trans. Joshua David Jordan (New York: Farrar, Straus and Giroux, 2018), 106.

${ }^{75}$ Greg Beckett, There Is No More Haiti: Between Life and Death in Port-au-Prince (Oakland: University of California Press, 2019), 44.
} 
Jesus as Savior must always bear in mind such victims. The need for healing and redemption is both universal and ongoing.

Again, Jesus' death involved no trick of the devil; there was only another pathetic story of governmental abuse of power, a religious hierarchy fearing a challenge, and most humans, then and now, failing to live and heed the prophetic, covenantal, and biblical message of humility, nonviolence, healing, and sacrifice. Betrayal, abandonment (save by the women), torture, and murder by the state echoes throughout time in our past, present, and future. How many have suffered needlessly and uselessly, as Lévinas writes ${ }^{76}$ or accumulated "useless knowledge" from the suffering they had to endure, as Charlotte Delbo (contra Richard Swinburne) warns, ${ }^{77}$ while we bicker over who is the greatest (Luke 22:24), and have the audacity to even question whether another religion (which we Christians believe God incarnate practiced!) is indeed genuinely and autonomously holy and salvific?

Is Jesus superfluous to salvation for Jews? A crafty (canon) lawyerly answer perhaps could say yes and no, so to be specific: does a devout Jew have to profess Jesus as the sole, unique, only savior in order to be saved? Can one answer "no" without recourse to platitudes like "the mystery of God's love" or "God works in mysterious ways"? Can someone be blissfully unaware of the literalness of Jesus, or reject or be unimpressed by claims of Jesus' unique role as a savior, ${ }^{78}$ and still find salvation through paths and means outside the sacramental church for salvation, which indeed may be pluralist and not uniform?

Let me return full circle. In my youthful experience on Long Island, we see fellow human beings, Jews, striving to live and be the good, whether as playmates, neighbors, teammates on the soccer team, or as a violinist adding musical pathos to a Good Friday liturgy. ${ }^{79}$ Of my experiences in Dublin, I am not implying the failures of the pastor of my local Catholic Church are representative symbols, or a synecdoche, of the Church's sinfulness. My local church and the universal Church have survived far worse hypocrites and misguided believers. I am simply stating the obviousness of our brokenness, our misty vision, our faulty listening and rash judgments.

Freud was wrong to claim that fear and neurosis made one cling to God. ${ }^{80} \mathrm{I}$ stand by my teacher, Elie Wiesel, that it is often harder to believe in God than

\footnotetext{
${ }^{76}$ Emmanuel Lévinas, "Useless Suffering," in The Problem of Evil: A Reader, ed. Mark Larrimore (Malden, MA: Blackwell, 2004), 371-80.

${ }^{77}$ Charlotte Delbo, Auschwitz and After, trans. Rosette C. Lamont (New Haven: Yale University Press, 1995), 115-231.

${ }^{78}$ I'm thinking here of a non-Jewish example: of Gandhi praising the Sermon on the Mount, but citing the Gita and Buddha as superior. See Mohandas K. Gandhi, An Autobiography: The Story of My Experiments with Truth (Boston: Beacon, 1957), 136-37.

${ }^{79}$ Note that aware of Amy-Jill Levine's critiques, I am not now erasing distinction and echoing Galatians 3:28: "There is no longer Jew or Greek, there is no longer slave or free, there is no longer male and female; for all of you are one in Christ Jesus." See Amy-Jill Levine, The Misunderstood Jew: The Church and the Scandal of the Jewish Jesus (New York: Harper, 2007), 125.

${ }^{80}$ Sigmund Freud, The Future of an Illusion, trans. James Strachey (New York: Norton, 1989), 62-63.
} 
renounce faith in God.$^{81}$ Remaining Catholic is painful while your kids see the Church's mistreatment and dehumanizing of them; while your wife cries in the vestibule because light and goodness seem ripped from a space once full of laughter and joy; where a 75-year-old faithful woman whose life was that weekly children's mass is curtly dismissed and told she is really not needed. Such faith is even more acutely questioned and doubted when we read of the Church's failures during the Shoah, in Argentina, in Rwanda, in Chile, amidst the Native peoples and the Africans and Aboriginal people. To believe can often seem impossible while the child abuse scandal continues to unravel with a lot of "business as usual" institutional responses (after perhaps a few mea culpas). These are the real stumbling blocks to faith (1 Corinthians 1:23).

It is too late for me. Again, when Jesus asks: "Do you also wish to go away?" (John 6:67), I stay rooted to the spot. This is not because I am some Peter, some rock (Matt 16:18). Where else would I go? Jesus has touched me in a way no other savior figure has. I can learn all the faiths in the world and it does not budge that core allegiance. This influences why I deeply believe other ways should also be supported, with the Jewish way being the easiest, no-brainer choice to commend. Of course, it is valid; of course it is salvific. This does not mean the Jewish faith and peoples are free from the need for repentance and growth. ${ }^{82}$ All faiths and humanist ideologies are in need of soul-searching, humility, and reform. What I envision as a Jesus of love and compassion, though, outpours from Jewish people, texts, and traditions. They both reflect and contribute to similar Christian hopes and beliefs.

Is Jesus for the Jews, superfluous to salvation? I think I can calmly, lovingly, and hopefully in a Christ-like, kenotic way, look my Jewish brothers and sisters in the eye, and say yes. Can I also gesture to the Muslim, the Hindu, the Buddhist, the Sikh, the Atheist, and so many other holy, but non-Christian people, and say, yes, too? This is the next and ongoing challenge, but Judaism is where Christians have to begin on such a path for its distinctive historical, biblical, and theological relationship with Jewish people, texts, and beliefs.

So, why take this stand? When I first publically presented this article as a paper, Gavin D'Costa rightly raised a perceptive question: based on my argument, why not simply stay agnostic on the question of salvation, both for Christians and others? Reflecting on his question, I asked myself: why the need to pronounce on what cannot ultimately be known or proved anyway?

The Catholic Church traditionally teaches it is best for us to live a sacramentally faithful and moral life within the Church. Salvation, at an individual level remains beyond any decision or claim of the Church and humanity. It rests solely with (and in) God. Such humility is essential, and yet it is more humbling to not

\footnotetext{
${ }^{81}$ Elie Wiesel, And the Sea Is Never Full: Memoirs, 1969-, trans. Marion Wiesel (New York: Knopf, 1999), 70.

${ }^{82}$ See, for example, the essays in Edward Feinstein, ed., Jews and Judaism in the 21 st Century: Human Responsibility. The Presence of God, and the Future of Covenant (Woodstock, VT: Jewish Lights, 2007).
} 
only question one's own way but to hope and believe in other ways, too. Believing and hoping for the salvific power and intrinsic meaning of other ways is an important moral and theological position. It highlights a God of all-encompassing, creative, expansive love, not tied down and limited by any human conception of religions as a negative zero sum game. Borrowing the term "multidirectional memory" from Michael Rothberg (in which honoring the historic injustice of other groups need not detract from your commitment for others to remember and honor your groups' suffering), ${ }^{83}$ perhaps we can support a multidirectional, interfaith, salvific hope.

Again: why take this stance? How can I pass on my own faith to my children without clear boundaries and judgments? None of this is simple or easy, but you'll still find me at the folk mass this Sunday at the Catholic Church in Rathmines. I don't plan on running off to worship Krishna or standing by Jesus' words in the Qur'an renouncing any who claim he is more than a messenger of God (5:120). If you push me, I'd say that Quranic passage needs to be seen as abrogated by another passage, or read differently.

Like Phan, I am comforted and perhaps inspired because of a perceived friendlier, Vatican stance towards interreligious theology, yet I hope my words would be stated even if such conditions become frostier. No one knows who will succeed Francis.

So, why take this stance? I am thinking of my children. These reflections have really been for them all along. I also think it's about the future health and integrity of the Church, if I can be so bold; and the real task of the community of God, which is to live as if all of creation is truly beloved by its Creator, and so promoting deep compassion and solidarity especially to the forsaken and marginalized.

None of these religious debates and arguments matter to my children, and I hear similar observations from many of my fellow theologians or religious believers. I don't think it's a failure on the next generation's part or because of some fake news conspiracy or the internet, and video games, or whatever else is blamed as the reasons for a majority of young people in Jewish and Christian western worlds with diminishing links and connections to institutional faith and religion. ${ }^{84}$ They are certainly no less kind and compassionate, but are almost too open and accepting of different ways of life. They don't need to grapple with this arcane and antediluvian "problem" anymore. It would be shameful and inexcusable if one of my progeny or current students have to fear going down this path professionally or spiritually, if the Church were to stumble back into a more Dominus Iesus mentality. The Jewish way and the Christian way; the Jewish covenant(s) and the Christian covenant(s); are salvific in themselves, and Jesus is both essential and superfluous to salvation for Jews. Jesus is essential because salvation must pass though love of

\footnotetext{
${ }^{83}$ Michael Rothberg, Multidirectional Memory: Remembering the Holocaust in the Age of Decolonization (Stanford: Stanford University Press, 2009).

${ }^{84}$ Pew Research Center, "Young adults around the world are less religious by several measures," (13 June 2018), https://www.pewforum.org/2018/06/13/young-adults-around-the-world-are-less-religiousby-several-measures/.
} 
others, especially the downtrodden, opposing political, military and religious corruption, but is superfluous because such moral callings can be heard long before any savior of Galilee, and God-willing, long after any death of the Church, too.

And now we need to see where the breadcrumbs keep going. 